\title{
NATO STANDARDIZATION DOCUMENTS FOR MINE COUNTERMEASURE AND THEIR UPDATING AS AN AREA OF SCIENTIFIC ACTIVITY
}

\author{
Karol Listewnik*, Piotr Kubis** \\ * Polish Naval Academy, Faculty of Navigation and Naval Weapons, Śmidowicza 69 Str., 81-127 \\ Gdynia, Poland; e-mail: k.listewnik@amw.gdynia.pl \\ ** Polish Navy Control and Measurement Unit, War Port Command, Gdynia, Rondo Bitwy pod Oliwa 1 Str., \\ 81-103 Gdynia, Poland; e-mail: piokubis@wp.pl
}

\begin{abstract}
NATO standardization documents are the basis for action in many areas of NATO military activity and their affiliated organizations. The development of the NATO standardization documentation has been on-going for more than 60 years, and their content provides a reliable basis for joint action in a unified manner, enabling interoperability in many areas of NATO operations. The article is divided into three parts, the first of which deals with the general principles of NATO standardization, the second part describes the standardization documents related to the measurement of the ship's signatures in aspect of the mine countermeasures and the third describes the participation in research project of NATO - RIMPASSE 2011 Trial. One of the their task was to verify and update NATO standardization documents including AMP-15.
\end{abstract}

Key words:

NATO standardization documents, STANAG, interoperability, ship's signatures measurements and ranges, mine countermeasures, MCM.

Research article

(C) 2018 Karol Listewnik, Piotr Kubis This is an open access article licensed under the Creative Commons Attribution-NonCommercial-NoDerivatives 4.0 license (http://creativecommons.org/licenses/by-nc-nd/4.0/) 


\section{INTRODUCTION}

The knowledge of NATO standardization documents is essential in the development of procedures, methods in new areas of operation, the development of new military equipment and its exploitation. After NATO GLOSSARY OF STANDARDIZATION TERMS AND DEFINITIONS (ENGLISH AND FRENCH) AAP-42 [6] NATO standardization is defined as the development and implementation of concepts, doctrines, procedures and designs in order to achieve and maintain the compatibility, interchange ability or commonality which are necessary to attain the required level of interoperability, or to optimise the use of resources, in the fields of operations, materiel and administration'. Standardization in NATO is a result of NATO's established policy for interoperability which is defined as 'the ability to act together coherently, effectively and efficiently to achieve Allied tactical, operational and strategic objectives' [10]. NATO Policy for Standardization contents NATO Framework for Civil Standards and together with Defence Planning Process through AAP-52 Guidance On Top-Down Standardization and AAP-03 Production, Maintenance And Management Of NATO Standardization Documents initiates the implementation process of NATO Standards documents.

NATO replicates the concept of ISO/IEC'1 standards as 'a standard is a document, established by consensus and approved by a recognized body that provides, for common and repeated use, rules, guidelines or characteristics for activities or their results, aimed at the achievement of the optimum degree of order in a given context'. It is important that the standards are based on multiple sources: 'a standard should be based on the consolidated results of science, technology, experience and lessons learned' [6,7], which reflects the idea of summarizing knowledge at some mature stage of research, development and technologies in a given topic in the standard. General use of civil standards is defined by NATO Framework For Civil Standards: 'The Alliance will use suitable civil standards to the maximum practicable extent unless there are compelling reasons not to do so. Only where no applicable civil standard is available, will a NATO standard be developed'.

In general, the standardization process involves the development, ratification and subsequent publication of standardization documents that result from the Standardization Objectives contained in the NATO Standardization Program and the Standardization Initiatives, which are primarily initiated by specialized NATO agendas. This process Commission.

${ }^{1}$ ISO/IEC: International Organization for Standardization/International Electrotechnical 
ends with the implementation (publication) of the published document or its updating, as well as the bilateral or multilateral agreements resulting from the work in specific NATO bodies.

\section{CHARACTERIZATION OF NATO STANDARDIZATION DOCUMENTS}

The basic NATO standardization documents (fig. 1) include:

- STANAG (Standardization Agreement) - Standardization Agreement;

- AP (Allied Publication) - Allied Publication.

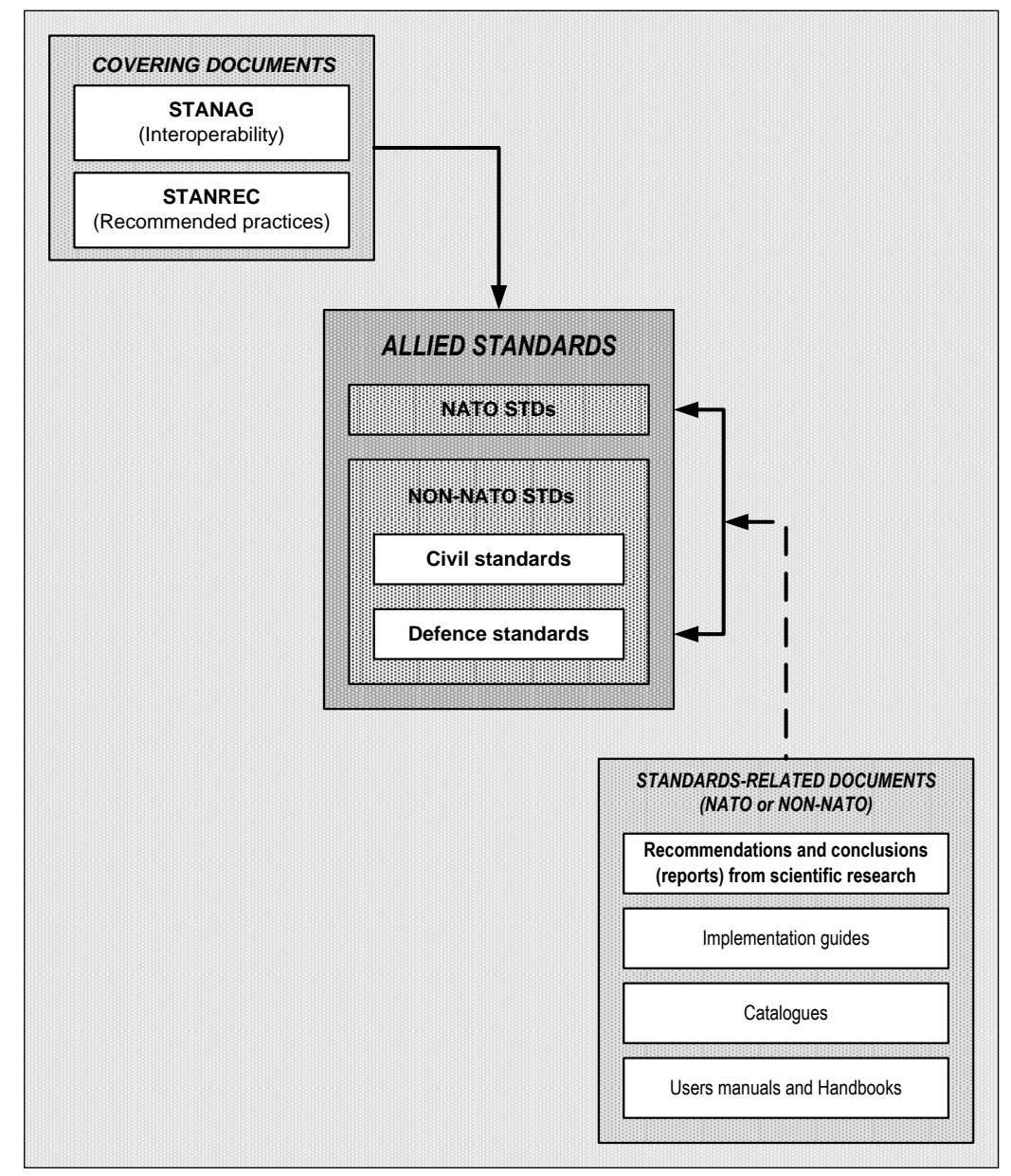

Fig. 1. NATO Standardization Documents [AAP-03 Ed. J, Ver. 1, NOVEMBER 2010 with authors modification] 
STANAG (Standardization Agreement) - this is a memorandum of understanding between several or all Member States on the use of the same or similar military equipment, ammunition, supplies and stocks as well as operational, logistic and administrative procedures.

The content of the STANAG document includes:

- list of appointed documents (if applicable);

- objective (obligatory);

- agreement (obligatory);

- terms and definitions (if applicable);

- general information (if enhanced);

- details of the agreement (if applicable);

- protection of rights (if applicable);

- implementation of the agreement (obligatory);

- appendices and appendices (if applicable).

The numbering of STANAGs and STANRECs (NATO standardization recommendation) is related to the institution preparing the document according to the table 1.

AP - Allied Publication - it is the official NATO standardization document for which all or several NATO countries agree as a common implementation document distributed to the user level. National Acceptance of NATO Allied Publications issued by the NATO Standardization Agency may be entered into as a Standardization Agreement, which contains information on the ratification and implementation of the provisions of this AP.

There are three types of AP documents:

- AP documents containing only basic information, so that there is no need to cover them with STANAG;

- AP documents recommending, in certain circumstances, action by implementing countries. They require approval by Member States in the form of ratification of STANAG;

- a combination of the above, i.e. material information, which does not require ratification and recommendations, which, as directives, they impose the necessity of approval by ratifying as STANAG.

Depending on the subject matter of the publication, it is assigned the title and abbreviated title according to the table 2 . 
NATO standardization documents for mine countermeasure...

Tab. 1. STANAG and STANREC numbering scheme [own study]

\begin{tabular}{|c|c|c|c|}
\hline Series & $\begin{array}{l}\text { Sponsors } \\
\text { (short title) }\end{array}$ & Sponsors (full title) & $\begin{array}{l}\text { NATO Supporting } \\
\text { Staff }\end{array}$ \\
\hline 1000 & MCMSB & $\begin{array}{l}\text { Military Committee Maritime } \\
\text { Standardization Board }\end{array}$ & $\begin{array}{c}\text { NSA - NATO } \\
\text { Standardization } \\
\text { Agency, Naval Branch }\end{array}$ \\
\hline 2000 & MCLSB & $\begin{array}{l}\text { Military Committee Land } \\
\text { Standardization Board }\end{array}$ & NSA, Army Branch \\
\hline 2500 & MCJSB & $\begin{array}{l}\text { Military Committee Joint } \\
\text { Standardization Board }\end{array}$ & NSA, Joint Branch \\
\hline 3000 & $\begin{array}{c}\text { MCASB } \\
\text { and NATMC }\end{array}$ & $\begin{array}{l}\text { Military Committee Air Standardization } \\
\text { Board and National Military Committee }\end{array}$ & NSA, Air Branch \\
\hline 4000 & C3B and CNAD & $\begin{array}{c}\text { Consultation, Command and Control } \\
\text { Board and Conference of National } \\
\text { Armaments Directors }\end{array}$ & $\begin{array}{l}\text { NATO Headquarters } \\
\text { C3 Staff, IS - Interna- } \\
\text { tional Staff, Defence } \\
\text { Investment Div. }\end{array}$ \\
\hline 5000 & C3B & Consultation, Command and Control Board & $\begin{array}{l}\text { NATO Headquarters } \\
\text { C3 Staff } \\
\end{array}$ \\
\hline 6000 & $\begin{array}{l}\text { MC other } \\
\text { than MCSBs }\end{array}$ & $\begin{array}{l}\text { Military Committees other than Military } \\
\text { Committee Standardization Boards }\end{array}$ & $\begin{array}{c}\text { IS, Defence } \\
\text { Investment Div. }\end{array}$ \\
\hline 7000 & ATMC & Air Traffic Management Committee & $\begin{array}{c}\text { IS, Defence } \\
\text { Investment Div. }\end{array}$ \\
\hline 8000 & RTB & Research and Technology Board & $\begin{array}{c}\text { IS, Defence } \\
\text { Investment Div. }\end{array}$ \\
\hline 8500 & SCEPC & $\begin{array}{l}\text { Senior Civil Emergency Planning } \\
\text { Committee }\end{array}$ & $\begin{array}{l}\text { Heads of the National } \\
\text { Civil Emergency } \\
\text { Planning Organisations } \\
\text { from NATO and partner } \\
\text { countries }\end{array}$ \\
\hline
\end{tabular}

Tab. 2. Examples of Allied and Multinational Publications [own study]

\begin{tabular}{|l|c|c|c|c|}
\hline No. & AP & Definition & $\begin{array}{c}\text { Sponsors } \\
\text { (short title) }\end{array}$ & $\begin{array}{c}\text { Sponsors } \\
\text { (full title) }\end{array}$ \\
\hline 1. & AACP & Acquisition (Practices) & $\begin{array}{c}\text { LCMG } \\
\text { (AC/327) }\end{array}$ & $\begin{array}{c}\text { Life Cycle } \\
\text { Management Group }\end{array}$ \\
\hline 2. & AAP & Administrative & All TAs & $\begin{array}{c}\text { All Tasking } \\
\text { Authorities }\end{array}$ \\
\hline 3. & ACAMP & Camouflage and Concealment & RTB (AC/323) & $\begin{array}{c}\text { Research and } \\
\text { Technology Board }\end{array}$ \\
\hline 4. & ACMP & Configuration Management & $\begin{array}{c}\text { LCMG } \\
\text { (AC/327) }\end{array}$ & $\begin{array}{c}\text { Life Cycle } \\
\text { Management Group }\end{array}$ \\
\hline 5. & AComP & Communication & C3B (AC/322) & $\begin{array}{c}\text { Consultation, } \\
\text { Command and } \\
\text { Control Board }\end{array}$ \\
\hline
\end{tabular}




\begin{tabular}{|c|c|c|c|c|}
\hline No. & AP & Definition & $\begin{array}{l}\text { Sponsors } \\
\text { (short title) }\end{array}$ & $\begin{array}{l}\text { Sponsors } \\
\text { (full title) }\end{array}$ \\
\hline 6. & ADatP & Data (Processing) & $\begin{array}{c}\mathrm{C} 3 \mathrm{~B} \\
(\mathrm{AC} / 322)\end{array}$ & $\begin{array}{l}\text { Consultation, } \\
\text { Command and } \\
\text { Control Board }\end{array}$ \\
\hline 7. & ADivP & Diving & MCMSB & $\begin{array}{l}\text { Military Committee } \\
\text { Maritime } \\
\text { Standardization } \\
\text { Board } \\
\end{array}$ \\
\hline 8. & AECP & Electromagnetic Compatibility & $\begin{array}{c}\text { LCMG } \\
\text { (AC/327) } \\
\text { MCMSB }\end{array}$ & $\begin{array}{c}\text { Life Cycle } \\
\text { Management Group }\end{array}$ \\
\hline 9. & АECTP & Environmental Conditions and Test & $\begin{array}{c}\text { LCMG } \\
(\mathrm{AC} / 327) \\
\end{array}$ & $\begin{array}{c}\text { Life Cycle } \\
\text { Management Group }\end{array}$ \\
\hline 10. & AEDP & Engineering Documentation & $\begin{array}{c}\text { CNAD } \\
(\text { AC/259) } \\
\text { LCMG } \\
(\text { AC/327) } \\
\text { NAFAG } \\
(\mathrm{AC} / 224)\end{array}$ & $\begin{array}{c}\text { Conference } \\
\text { of National } \\
\text { Armament Directors, } \\
\text { Life Cycle } \\
\text { Management Group, } \\
\text { NATO Air Force } \\
\text { Armaments Group } \\
\end{array}$ \\
\hline 11. & AEngrP & Military Engineering & MCLSB & $\begin{array}{c}\text { Military Committee } \\
\text { Land Standardization } \\
\text { Board }\end{array}$ \\
\hline 12. & AEP & Engineering & $\begin{array}{l}\text { MCMBs CNAD } \\
(\mathrm{AC} / 229)\end{array}$ & $\begin{array}{l}\text { Military Committee } \\
\text { Management Board, } \\
\text { Conference } \\
\text { of National } \\
\text { Armament Directors }\end{array}$ \\
\hline 13. & AEPP & Engineering Practices & $\begin{array}{c}\text { LCMG } \\
(\mathrm{AC} / 327)\end{array}$ & $\begin{array}{c}\text { Life Cycle } \\
\text { Management Group }\end{array}$ \\
\hline 14. & AEtP & Electronics & $\begin{array}{c}\text { C3B (AC/322) } \\
\text { ATMC (AC/92) } \\
\text { LCMG } \\
(\mathrm{AC} / 327)\end{array}$ & $\begin{array}{c}\text { Consultation, } \\
\text { Command and } \\
\text { Control Board, Air } \\
\text { Traffic Management } \\
\text { Committee, Life Cycle } \\
\text { Management Group }\end{array}$ \\
\hline 15. & AFP & $\begin{array}{c}\text { FORACS } \\
\text { Note: FORACS is 'forces sensors and } \\
\text { weapons accuracy check site' }\end{array}$ & $\begin{array}{c}\text { CNAD } \\
(\mathrm{AC} / 259)\end{array}$ & $\begin{array}{c}\text { Conference } \\
\text { of National } \\
\text { Armament Directors }\end{array}$ \\
\hline 16. & AGeoP & Geographic & MCJSB & $\begin{array}{c}\text { Military Committee } \\
\text { Join Standardization } \\
\text { Board } \\
\end{array}$ \\
\hline 17. & AHP & Hydrographic & MCMSB & $\begin{array}{l}\text { Military Committee } \\
\text { Maritime } \\
\text { Standardization } \\
\text { Board }\end{array}$ \\
\hline
\end{tabular}


NATO standardization documents for mine countermeasure...

\begin{tabular}{|c|c|c|c|c|}
\hline No. & AP & Definition & $\begin{array}{l}\text { Sponsors } \\
\text { (short title) }\end{array}$ & $\begin{array}{l}\text { Sponsors } \\
\text { (full title) }\end{array}$ \\
\hline 18. & AIntP & Intelligence & MCJSB & $\begin{array}{c}\text { Military Committee } \\
\text { Joint Standardization } \\
\text { Board }\end{array}$ \\
\hline 19. & AISP & Imagery System & $\begin{array}{c}\text { CNAD } \\
(\mathrm{AC} / 259) \mathrm{RTB} \\
(\mathrm{AC} / 323)\end{array}$ & $\begin{array}{c}\text { Conference } \\
\text { of National } \\
\text { Armament Directors, } \\
\text { Research and } \\
\text { Technology Board }\end{array}$ \\
\hline 20. & ALCCP & Life Cycle Costs & $\begin{array}{c}\text { LCMG } \\
(\mathrm{AC} / 327)\end{array}$ & $\begin{array}{c}\text { Life Cycle } \\
\text { Management Group }\end{array}$ \\
\hline 21. & ALP & Logistics & $\begin{array}{c}\text { CNAD } \\
(\mathrm{AC} / 259) \\
\mathrm{LC}(\mathrm{AC} / 305) \\
\mathrm{MCSBs}\end{array}$ & $\begin{array}{c}\text { Conference } \\
\text { of National } \\
\text { Armament Directors }\end{array}$ \\
\hline 22. & AMEPP & Maritime Environmental Protection & $\begin{array}{c}\text { NAAG } \\
\text { (AC/225) } \\
\text { MCJSB }\end{array}$ & $\begin{array}{c}\text { NATO Army } \\
\text { Armaments Group }\end{array}$ \\
\hline 23. & AMP & Mine Warfare & MCMSB & $\begin{array}{c}\text { Military Committee } \\
\text { Maritime } \\
\text { Standardization } \\
\text { Board } \\
\end{array}$ \\
\hline 24. & AMSP & Modelling and Simulation & $\begin{array}{c}\text { CNAD } \\
(\mathrm{AC} / 259) \\
\mathrm{RTB}(\mathrm{AC} / 323)\end{array}$ & $\begin{array}{c}\text { Conference } \\
\text { of National } \\
\text { Armament Directors, } \\
\text { Research and } \\
\text { Technology Board }\end{array}$ \\
\hline 25. & ANEP & Naval Engineering & $\begin{array}{c}\text { NAAG } \\
(\mathrm{AC} / 225) \\
\text { NNAG } \\
(\mathrm{AC} / 141) \\
\end{array}$ & $\begin{array}{c}\text { NATO Army } \\
\text { Armaments Group, } \\
\text { NATO Naval } \\
\text { Armaments Group } \\
\end{array}$ \\
\hline 26. & ANP & Navigation & $\begin{array}{l}\text { C3B (AC/322) } \\
\text { ATMC (AC/92) }\end{array}$ & $\begin{array}{c}\text { Consultation, } \\
\text { Command and } \\
\text { Control Board, Air } \\
\text { Traffic Management } \\
\text { Committee }\end{array}$ \\
\hline 27. & APP & Procedural & MCMSB & $\begin{array}{c}\text { Military Committee } \\
\text { Maritime } \\
\text { Standardization } \\
\text { Board }\end{array}$ \\
\hline 28. & AQAP & Quality Assurance & $\begin{array}{c}\text { LCMG } \\
(\mathrm{AC} / 327)\end{array}$ & $\begin{array}{c}\text { Life Cycle } \\
\text { Management Group }\end{array}$ \\
\hline 29. & ARMP & Reliability and Maintainability & $\begin{array}{c}\text { LCMG } \\
(\mathrm{AC} / 327)\end{array}$ & $\begin{array}{c}\text { Life Cycle } \\
\text { Management Group }\end{array}$ \\
\hline 30. & ATP & Tactical & $\begin{array}{l}\text { MCSBs } \\
\text { NEWAC }\end{array}$ & $\begin{array}{l}\text { Military Committee } \\
\text { Standardization } \\
\text { Boards, NATO } \\
\text { Electronic Warfare } \\
\text { Advisory Committee }\end{array}$ \\
\hline
\end{tabular}




\begin{tabular}{|c|c|c|c|c|}
\hline No. & AP & Definition & $\begin{array}{c}\text { Sponsors } \\
\text { (short title) }\end{array}$ & $\begin{array}{c}\text { Sponsors } \\
\text { (full title) }\end{array}$ \\
\hline 31. & ATrainP & Education and Training & MC/NTG & $\begin{array}{c}\text { Military Committee } \\
\text { /NATO Training } \\
\text { Group }\end{array}$ \\
\hline 32. & AVTP & Vehicle Testing & NAAG & $\begin{array}{c}\text { NATO Army } \\
\text { Armaments Group }\end{array}$ \\
\hline 33. & AWP & Weather & MCMG & $\begin{array}{c}\text { Military Committee } \\
\text { Meteorological } \\
\text { Group }\end{array}$ \\
\hline 34. & AXP & Exercise & MCJSB & $\begin{array}{c}\text { Military Committee } \\
\text { Join Standardization } \\
\text { Board, Military } \\
\text { Committee Maritime } \\
\text { Standardization } \\
\text { Board }\end{array}$ \\
\hline 35. & EXTAC & Experimental Tactic & MCMSB & $\begin{array}{c}\text { Military Committee } \\
\text { Standardization } \\
\text { Boards }\end{array}$ \\
\hline
\end{tabular}

Note: The selection of the APs defined in the table is resulted their association with the MCM area.

Each publication has its own number, e.g. ATP-1, ATP-6, etc., and the lettering of the next edition and edition, e.g. ATP-1 (C). All publications are valid as soon as the required majority of the Member States ratifies the STANAG insertion order and when the publication date of the NATO publication is stated.

\section{SELECTED NATO STANDARDIZATION DOCUMENTS FOR MEASURING SHIPS SIGNATURES AND MCM}

Navy forces associated with the mine countermeasure activities are c.a. $35 \%$ of the Polish Navy. The selected NATO standardization documents for measuring ships signatures and MCM area are shown in table 3.

Due to the wide nature of the issue, the characteristics of the documents will be based on the standardization documents on the measurement and minimization of physical fields in the lower half-sphere, in particular magnetic and acoustic fields. The basic documents covering the above mentioned The issues listed in the table above are the following:

- AMP-4 [7];

- AMP-14 [8];

- AMP-15 [9]. 
NATO standardization documents for mine countermeasure...

Tab. 3. STANAGs and APs for measuring ships signatures and MCM [own study]

\begin{tabular}{|l|l|}
\hline STANAG 1090 & $\begin{array}{l}\text { Standards for use when measuring and reporting acoustic characteristics } \\
\text { of mine countermeasures vessels and mine countermeasures helicopters } \\
\text { of the North Atlantic Treaty navies, standards for use when measuring } \\
\text { and reporting acoustic characteristics of warships and merchant ships } \\
\text { in relation to mine risks }\end{array}$ \\
\hline STANAG 1364 & Standard magnetic and acoustic criteria for intervention vehicles \\
\hline $\begin{array}{l}\text { STANAG 1203 } \\
\text { AMP-4(B) NAVY }\end{array}$ & $\begin{array}{l}\text { Degaussing and acoustic ranging information concerning North Atlantic } \\
\text { Treaty minesweepers and mine hunters }\end{array}$ \\
\hline STANAG 1254 & Standardized magnetic safety parameters for ships and MCM vehicles \\
\hline STANAG 1310 & $\begin{array}{l}\text { Design criteria for replenishment aspects of new construction naval } \\
\text { vessels }\end{array}$ \\
\hline STANAG 1333 & Protection of vessels from electro-magnetic mines \\
\hline AMP-14 & $\begin{array}{l}\text { Methods of determining and reducing the risk from pressure combination } \\
\text { mines }\end{array}$ \\
\hline STANAG 1413 & Extremely low frequency electromagnetic silencing \\
\hline STANAG 1415 & $\begin{array}{l}\text { Objectives and techniques for static magnetic silencing of ferromagnetic } \\
\text { ships }\end{array}$ \\
\hline $\begin{array}{l}\text { STANAG 1418 } \\
\text { AMP-15 }\end{array}$ & Standards for mine warfare acoustic measurement \\
\hline $\begin{array}{l}\text { STANAG 1431 } \\
\text { AMP-15 Conf. Supp. }\end{array}$ & $\begin{array}{l}\text { Confidential supplement to standards for mine warfare acoustic meas- } \\
\text { urements }\end{array}$ \\
\hline
\end{tabular}

\section{AMP-4(B) NAVY}

The publication Degaussing and acoustic ranging information concerning North Atlantic Treaty minesweepers and mine hunters consists of chapters. Chapter 1, introductory, is divided into three sections:

1. Section I - Purpose of Application AMP-4 (B) (NAVY). The purpose of this publication is to provide the following operational information to Operational Commands, land bases, Demagnetisation and Acoustic Ranges:

a) information on demagnetisation of trawlers in all NATO member countries;

b) details of the demagnetisation sites of all NATO member countries;

c) details of the stations for the measurement of acoustic fields of all NATO member countries.

2. Section II - Information that every trawler should provide to a measurement station before a range measurement.

In terms of demagnetization, the information includes:

a) demagnetization plan containing base settings for degaussing units and No DGC if the unit has previously undergone magnetic field measurements; 
b) degaussing certificate or data sheet showing the winding location, number of coils and position of the distribution boxes;

c) drawing or stowage plan showing the location of ferromagnetic materials;

d) the results of insulation resistance measurement of degaussing windings, if previously performed.

In terms of acoustic measurements, the information includes:

a) the results of acoustic measurements, if possible, should have been made beforehand; acoustic measurements are designed to demonstrate that all factors that reduce the acoustic field of a ship are in good order and that the ship's mechanical devices and propellers do not produce excessive noise;

b) standard acoustic characteristics if the unit was previously measured.

3. Section III - Definitions, this section defines:

a) magnetic characteristics;

b) Demagnetization Code Number;

c) depth code used during magnetic field measurements and degaussing process;

d) acoustic reference depth.

The following chapters contain information on MCM ships, demagnetisation and measurements ranges, measurements of magnetic and acoustic fields of individual NATO countries.

Each chapter devoted to one country is divided into sections:

1. Section I - Information on MCM vessels. The section contains data:

a) general types of MCM vessels;

b) on board degaussing system (types of demagnetization windings, type of degaussing system);

c) recommended measuring ranges;

d) degaussing process and magnetic and acoustic measurements on the ship.

2. Section II - Degaussing systems. The section contains data on training stations and demagnetization stations and magnetic field measurements, such as:

a) address;

b) telephone/fax;

c) radio communication;

d) range data (range parameters, measurement possibilities, hours worked, order and measurement conditions, maps showing the location of the range, etc.).

3. Section III - Acoustic Measurement Equipment. The section contains data on acoustic fields and test ranges analogous to those given in Section II. 
Above is presented the typical structure of NATO standardization document. Below in the subsequent chapters devoted to specific STANAGs, only the general content will be presented.

\section{AMP-14}

The basic purpose of AMP 14 is to determine the levels of permissible values and standard procedures for minimizing permanent and variable magnetic and electric fields for both ammunition ships (mainly trawlers and mine destroyers) and ferromagnetic hulls. The introduction of the above standards improves efficiency in the planning and management of combined operations involving mine action, by providing the necessary information and the desired flexibility of the interoperability of equipment and specialized equipment (measurement and degaussing) of the various NATO Member States. Based on the assumptions, the document is to be used at the operational and planning level.

The ship is a gathering of many sources of electromagnetic fields that can be used by sea mines. The main sources of magnetic field, electric constant, magnetic and alternating electric constant are: permanent magnetization and, resulting from the influence of the magnetic field, magnetization induced ferromagnetic materials of the ship's hull and its equipment, vortex currents resulting from the ship's motion in the earth's magnetic field, Diffused fields generated by electric machines (generators, motors), corrosive currents and their constituent variables due to the rotating propeller shaft of the ship, and disturbance fields from the marine mains network (e.g. $60 \mathrm{~Hz}$ ) and its harmonics.

The ship's electromagnetic field is minimized in two ways. The first is to eliminate or minimizing field sources, by using non-conductive and non-corrodible materials, and by demagnetizing and effective grounding of ship equipment. The other way is to produce a compensating field of equal shape on the ship, which is a compensated but opposite polarity.

The publication AMP-14 contains details procedures from demagnetisation methods and methods, through the measurement and calibration of magnetic and electrical magnetic minimization systems, to the production of protocols and documentation on the state of the electromagnetic fields of the ship. 


\section{AMP-15}

AMP-15 'Standards for naval mine warfare acoustic measurements' covers necessary types of measuring and reporting acoustic information and setting goals for acoustic signature to counter the threat from acoustic naval sea mines to naval mine countermeasures vehicles, warships, merchant vessels, naval mine countermeasures helicopters, divers, remotely operated vehicles and untethered unmanned vehicles.

The general aim of AMP-15 is to provide procedures for the measurement and reporting of acoustic signature information and for the establishment of acoustic signature procedures to countermeasure the naval sea mine threat to Allied and National Commands. AMP-15 is intended for application at all measurement, planning, operational and tactical levels. two research projects of NATO and the European Defence Agency.

\section{RESEARCH PROJECTS OF NATO FOR UPDATING STANDARDS}

The NATO Working Group SET-166 Signature Management System for Underwater Signatures of Surface Ships of the STO (Science and Technology Organization, former Research and Technology Agency) was established in Portsmouth (UK) at the end of September 2010 as a result of two years of cooperation between Canada, Germany and The Netherlands. The Ministry of Defence of Australia, Denmark, France, Norway, the United Kingdom, the United States of America, Sweden and Poland have expressed their will to cooperate with the Signatures Management System through the RIMPASSE 2011 (Radar InfraRed Electro-Magnetic Pressure Acoustic Ship Signature Experiments).

The objective of SET-166 was to develop requirements, information and tools [1] for the (national or joint international) development of Integrated Ship Signature Management Systems (ISSMS). More detailed objectives were to:

- evaluate methods to obtain information on the actual state of the ship as observed by the threat and to identify what could and needs to be done to optimize the real-time signature while maintaining coherence with the management of other signatures;

- to develop and demonstrate the capability to monitor the actual underwater signatures in real-time with sufficient accuracy for subsequent susceptibility analysis; 
- provide operators with an indication of the likely current susceptibility and capabilities of the ship and hence influence tactical decisions; this may include an indication of the underwater acoustic and electromagnetic signatures of the ship at that time and place (e.g. whether it is 'good' or 'bad');

- propose an outline design for a ship signature management system, ready for national implementation.

The main objective of the acoustic trials is to obtain a common data set to be used for development of acoustic signature monitoring, prediction and management systems in national (and joint international) projects.

A secondary objective is to obtain a common data set to be used for an evaluation of the differences in reported ship acoustic signatures at different ranges, due to range propagation and environmental effects, in particular to support an update of the AMP-15 procedure for measuring surface ship acoustic signatures in relation to mine threat.

To the research was selected measuring ranges in Canada, the United Kingdom, Norway, Germany and France (11 test sites) and two research vessels:

- Canadian single-hull research vessel QUEST;

- German double-hull research vessel PLANET.

Vessels are equipped with special sets of sensors, including active (effectors, e.g. shakers, towed sources).

CSSM stands for the Center of Ship Signature Management and is a joint German-Dutch organization that disseminated the data collected in cooperation with SET-166.

Polish Naval Academy in Gdynia participated in the signatures measurements trial of QUEST and PLANET research vessels, in cooperation with ASCHAU range in Germany, 14.09-06.10.2011. PNA took part in the framework of the RIMPASSE 2011 with a own production demonstration of technology acronym IGLOO in the form of multi-sensor mobile measurement module. Another task was the development of measurement data in accordance with the agreed SET-166 data format and then the exchange of data between the members of the measuring groups of all participating countries.

In addition, the Naval Academy has been accredited for cooperation in the processing and analysis of acoustic and hydrodynamic field of measured test vessels. Results of comparison in area of pressure signatures published in Chapter 5.4 PRESSURE SIGNATURE in STO TECHNICAL REPORT TR-SET-166 Signature Management System for Underwater Signatures of Surface Ships [3]. The cooperation 
continued 3 years and counts from the founding meeting of the NATO STO Working Group SET-166 on 30.09.2010.

The first author play a role Polish SET-166 National Representatives in area of acoustic, electro-magnetic and pressure underwater signatures. The standard AMP-15 has been updated on 07.05.2013 as COMPLETE REVISION Change Type.

\section{CONCLUSIONS}

Defence $R \& D$ areas (research and development) should be based on knowledge of what has already been done in NATO standardization, how they are updated, and whether the research will allow for updates or the development of new standardization documents. With knowledge of previously developed documents, their strengths and weaknesses, and trends in improving interoperability, and lets avoid repetitions when researching new topics, build on already proven solutions, and contribute to updating existing solutions contained in NATO standardization documents. Unawareness of procedures and rules of operation of military equipment contained in them often leads to activities repetitions and in the worst case to deal with matters already described and ordered.

Benefits of RIMPASSE 2011 Trial [3]:

- comparison of the technological potential of mobile and stationary measurement ranges of ships signatures - very good reproducibility of collected data;

- calibration of NATO measurement systems - all should specify the same character of the signature and if not the correct correction method;

- access to data recorded on other ranges (PNA measured on one, data obtained from ranges in Canada, the Great Britain, Norway, Germany and France, and from the QUEST and PLANET double-hull);

- participation in the revision of NATO standardization documents before they are published;

- dissemination of research results through publicity at major conferences [2, 4, 5];

- building its own technological potential in the field of command support systems for passive mine defence and constructing multi-influence underwater sensors devices.

- the data from TRIMPASSE 2011 Trial were used to compare Polish signatures measurement ranges using the PNA IGLOO system. 


\section{REFERENCES}

[1] CSSM, Master Trial Plan RIMPASSE 2011 v7.0, CSSM-2011-03, Germany, Kiel 2011.

[2] De Jong C. A. F. et al., Measuring Ship Acoustic Signatures Against Mine Threat, Proceedings of the 11th European Conference on Underwater Acoustics - ECUA 2012, 2-6 July 2012, Edinburgh, UK.

[3] Final Report of Task Group SET-166: Signature Management System for Underwater Signatures of Surface Ships, group work, STO, Brussels 2014.

[4] Gloza I., Buszman K., Listewnik K., The passive module for underwater environment monitoring, 11th European Conference on Underwater Acoustics - ECUA 2012, 2-6 July 2012, Edinburgh, UK.

[5] Homm A., Data evaluation of underwater radiated noise of ships in relation with directivity, Conf. Proceedings, AIA-DAGA 2013, Merano, Italy.

[6] NATO Glossary of Standardization Terms and Definitions (English and French) AAP-42, NOTICE AC/281-N(2009)0066-REV2 dated 16/7/2009.

[7] STANAG 1203, AMP-4, Degaussing and acoustic ranging information concerning North Atlantic Treaty minesweepers and mine hunters, Change 5, August 2010, North Atlantic Treaty Organization, Military Agency For Standardization (MAS), Brussels 2010.

[8] STANAG 1333, AMP-14, Protection of vessels from electro-magnetic mines, Change 6, February 2002, North Atlantic Treaty Organization, Military Agency For Standardization (MAS), Brussels 2002 .

[9] STANAG 1418, AMP-15, Standards for mine warfare acoustic measurements, Change 2, May 2013, North Atlantic Treaty Organization, Military Agency For Standardization (MAS), Brussels 2013.

[10] Standardization and Related Activities — General Vocabulary ISO/IEC Guide 2.

\section{DOKUMENTY STANDARYZACYJNE NATO W ZAKRESIE PRZECIWDZIAŁANIA MINOWEGO ORAZ ICH AKTUALIZACJA JAKO OBSZAR DZIAŁAŃ NAUKOWYCH}

\section{STRESZCZENIE}

Dokumenty standaryzacyjne NATO są podstawą działania w wielu obszarach aktywności wojsk NATO i stowarzyszonych z nimi organizacji. Rozwój dokumentacji standaryzacyjnej NATO trwa od ponad sześćdziesięciu lat i ich zawartość stanowi rzetelną podstawę do wspólnego działania w zunifikowany sposób, umożliwiając interoperacyjność w wielu dziedzinach działań wojsk NATO. 
Artykuł podzielono na trzy części, z których pierwsza przybliża ogólne zasady normalizacji w NATO, druga zawiera opis dokumentów standaryzacyjnych związanych z pomiarami pól fizycznych okrętu oraz obroną przeciwminową, trzecia zaś opisuje udział w projekcie badawczym NATO — badania RIMPASSE 2011, którego jednym z zadań była weryfikacja i aktualizacja dokumentów standaryzacyjnych NATO, w tym AMP-15.

\title{
Słowa kluczowe:
}

dokumenty standaryzacyjne NATO, STANAG, interoperacyjność, pomiary pól fizycznych okrętu, obrona przeciwminowa okrętu.

\author{
Article history \\ Received: 13.11.2017 \\ Reviewed: 29.01.2018 \\ Revised: $\quad 21.02 .2018$ \\ Accepted: $\quad 22.02 .2018$
}

